\section{Bakurova A., Ropalo H., Tereschenko E.}

\title{
MODELING OF OPTIMAL PORTFOLIO OF CLIENTS OF CENTRALIZED PHARMACY NETWORK
}

Об’єкт даного дослідження визначає управління ризиками централізованої аптечної мережі, що пов’язані з маркетингом відносин між мережею та різними групами клієнтів. Розвиток конкурентного ринку призводить аптечні мережі до необхідності вести діалог з клієнтом, надаючи йому певні переваги, тим самим зменшувати власні ризики. Предметом дослідження є моделювання оптимального портфелю клієнтів централізованої аптечної мережі як одного з інструментів управління ризиками.

Спираючись на основи портфельної теорії Марковіца та багатокритеріальної оптимізації, в даній роботі побудовано базову модель оптимального портфелю клієнтів централізованої аптечної мережі, що враховує три групи клієнтів - лояльних, випадкових та інтернет-замовлення. На відміну від класичної двокритеріальної моделі (мінімізащія ризику при максимізації доходу) в модель додано критерій максимізації ентропії, що підсилює ефект диверсифікащї. Також розглянуто чотири модифікації базової моделі. Периа з них поглиблює аналіз портфелю клієнтів мережі до окремих аптек, що входять до иієї мережі. Три наступні моделюють різні маркетингові стратегіi, в яких перевага надається одній з груп клієнтів.

Для розв'язування відповідних до побудованих моделей багатокритеріальних задач розроблено програмне забезпечення в пакеті Matlab, за допомогою якого методом послідовних поступок знайдено множини парето-оптимальних портфелів клієнтів. Верифікацію моделей виконано на реальних даних, що були надані однією з аптечних мереж.

Моделювання оптимальних портфелів клієнтів централізованої аптечної мережі дозволяє усунути недоліки в управлінні мережею та обрати оптимальну комбінацію розподілу груп лояльних, випадкових та інтернет-клієнтів. Завдяки цьому забезпечується можливість впливати на ці групи споживачів, впроваджуючи відповідні програми лояльності, що в кінщевому рахунку веде до підвищення прибутку. Результати моделювання будуть корисними для автоматизащї бізнес-прощесів будь-яких торгівельних мереж, управління ризиками, аналізу програм лояльності для підвищення ефективності їхнього функціонування.

Ключові слова: аптечна мережа, лояльні клієнти, інтернет-клієнти, модель оптимального портфелю, багатокритеріальна задача.

Received date: 09.09.2019

Accepted date: 02.10.2019

Published date: 30.12 .2019
Copyright (C) 2019, Bakurova A., Ropalo H., Tereschenko E. This is an open access article under the CC BY license (http://creativecommons.org/licenses/by/4.0)

\section{Introduction}

The development of informatization of society predetermines the need to search for new methods and approaches to improve the efficient operation of enterprises. There is a shift in the emphasis of enterprises on attracting new consumers to existing ones by forming their loyalty. Management of the loyalty of the trading network consists in creating such a system for managing the activities of the enterprise that would make it possible, on the basis of analysis of the external and internal environment, to ensure the effective achievement of high economic ones. As well as social results through building long-term relationships with consumers [1].

If until recently, the focus of retail chains was their quantitative increase, then as a result of increased competition, as well as fluctuations in the country's economy, enterprises increasingly began to focus on developing dialogue with customers, on which the sustainable development of the company depends. Moreover, the effectiveness of such actions is ensured by the observance of the process, including several interrelated stages, in particular:

- assessment and analysis of the internal and external environment;

- determination of the strengths and weaknesses of the company;

- analysis of opportunities;

- determination of loyalty programs;

- implementation of the strategy;

- analytical study of the situation.

The author of [2] notes that $30 \%$ of customers bring $50 \%$ of losses, and according to Pareto law $20 \%$ of loyal customers bring $80 \%$ of profit. So, it is possible to conclude that loyal consumers bring the main profit of the enterprise. Moreover, not only consumers affect the welfare of the enterprise, the company's activities also affect the level of customer loyalty.

Consumer loyalty plays the role of the organization's competitive advantage; it arises as an indicator of the ability to carry out innovative transformations not only in the sale of goods, but also in the provision of various services. 
Therefore, it is relevant to study customer portfolio models that take into account the current conditions for the functioning of pharmacy network in a competitive market environment.

\section{The object of research and its technological audit}

The object of research is the risk management of a centralized pharmacy network related to the marketing of relations between the network and various customer groups.

A high-quality approach to managing retail outlets in a pharmacy network in a tough competitive market involves minimizing risks in the event of actual or potential reduction in pharmacy profitability.

One of the risk management tools is the diversification of the structural elements of a complex system of a centralized pharmacy network, in particular the customer portfolio, in achieving the strategic goals of the company:

- risk reduction;

- strengthening the financial stability of the network;

- stabilization of financial income;

- formation of the potential of competitiveness and insensitivity to market changes.

Any drug or medical product has certain properties that are attractive to a specific segment of consumers. The more consumer groups a pharmacy covers, the lower the risk of revenue loss.

The subject of research is the modeling of the optimal client portfolio of a centralized pharmacy network based on portfolio theory and multicriteria optimization. But, one of the problematic issues in modeling is the lack of dynamism of the Markowitz model, which in turn provides a large field of activity for further research.

\section{The aim and objectives of research}

The aim of research is building models for making decisions on choosing the optimal combination of the distribution of groups of loyal, random and Internet clients for the further development of programs for influencing these groups. To achieve the aim, it is necessary to complete the following tasks:

1. Build multi-criteria models with different sets of criteria to determine the optimal client portfolio of a centralized pharmacy network.

2. Verify the constructed models on the real data of one of the pharmacy network in Zaporizhzhia (Ukraine).

3. Formulate recommendations on the results of experiments.

\section{Research of existing solutions of the problem}

The studies are based on an in-depth study of works on portfolio theory, risk theory and multicriteria optimization.

The author of [3], analyzing the significance of the Markowitz portfolio theory [4] and its evolution, defines three important concepts: investment portfolio efficiency, diversification, and optimization concepts. It also proves that for the development of the modern theory of international portfolio investment, the portfolio paradigm has a dominant status. Although this statement can also be considered by the development of a network economy and electronic society.
How the Markowitz analysis extends to an extended definition of risk is shown in [5], and the evolution of the estimated risk models of one beta version, which represents market risk, to multivariate risk models is also traced. However, this work does not compare these models with other types of risk models.

The author of [6], based on a review of the research literature on the average dispersion model, geometric average model, and consumption model of investment throughout life, developed a set of practical guidelines for making decisions about the life portfolio. But the question remains about the conditions under which investment policies can change. An alternative solution to the problem described in [7] contains a discussion of lifelong patterns of consumption and investment.

Among the main directions of solving the problem of variability and reliability leading to poor-quality diversification, works can be singled out [8,9]. However, they did not address the issue of the advantages of a reliability-based approach over classic portfolio building in daily practice.

The authors of [10], based on Markowitz optimization, investigate the influence of information relations on the sensitivity of profit and cost forecasting. However, as the authors themselves note, their work quantifies the benefits of improving information parameters, but does not report on the costs of this.

The work [11] is devoted to modern formulations of the problems of multi-criteria optimization of the banking portfolio of assets based on the classical portfolio theory of Markowitz and methods of generalizing them to the case of a loan portfolio using various measures of credit risk. But this work is highly specialized for banking and does not consider the optimal portfolio in the broad sense.

The encyclopedic publication on pharmaceuticals [12] indicates the importance of horizontal and vertical diversification in the activities of pharmacy network. However, the ways to solve the problems of diversification in risk management practice are not considered in detail.

Thus, the results of the analysis of scientific sources allow to conclude that despite a significant number of studies on the formation of optimal portfolios, the unsolved problems of constructing models for assessing network risks. As well as a generalization of the classical portfolio optimization problem in the case of a portfolio of customer networks, in particular pharmacy.

\section{Methods of research}

During the execution of the research, general scientific and special research methods were applied:

- methods of analysis and synthesis - for preliminary analysis with the formation of the problem, the definition of goals, the definition of assumptions and risks; - method of mathematical modeling - to build a model of an optimal portfolio of customers of a centralized pharmacy network;

- method of consecutive concessions for solving multicriteria problems.

\section{Research results}

Let's distribute the customers of the pharmacy network into three groups: loyal (regular), random and Internet clients. Let's believe that all three groups of customers 
do not overlap. Loyal consumers are those who form the pharmacy's turnover and use discount cards. By accident all other visitors, with a small frequency of purchase. The task of the pharmacy chain is to increase the average check and the frequency of purchase for each group of customers. To formalize the model, let's introduce the following notation:

- $y_{1}-$ the share of loyal customers in the portfolio of customers of the pharmacy chain;

$-y_{2}-$ the proportion of random customers in the pharmacy chain;

- $y_{3}-$ the proportion of online pharmacy chain customers;

$-b_{i}-$ the average check for the $i$-th group of clients of the pharmacy chain (c. u.);

- $\bar{b}_{i}-$ the expected average check for the $i$-th group of customers of the pharmacy chain (c. u.);

- $q_{i}$-the average frequency of visits in the $i$-th group of customers of the pharmacy network;

$-\bar{q}_{i}$ - the expected average frequency of visits in the $i$-th group of customers of the pharmacy network. Risks in this situation are the failure to receive the average check from Risk1 loyal customers and reduce the frequency of visiting random Risk2 customers. Also in this model, two criteria are provided that correspond to the goals of maximizing profitability:

- Sum1 - total average frequency of visits to the pharmacy chain by customers;

- Sum2 - total average check for the network as a whole.

$$
\left\{\begin{array}{l}
\text { Risk } 1=\sum_{i=1}^{3} \sum_{j=1}^{3} y_{i} \cdot y_{j} \cdot\left(q_{i}-\bar{q}_{i}\right) \cdot\left(q_{j}-\bar{q}_{j}\right) \rightarrow \min , \\
\text { Risk } 2=\sum_{i=1}^{3} \sum_{j=1}^{3} y_{i} \cdot y_{j} \cdot\left(b_{i}-\bar{b}_{i}\right) \cdot\left(b_{j}-\bar{b}_{j}\right) \rightarrow \min \\
\text { Sum } 1=\sum_{i=1}^{3} y_{i} \cdot q_{i} \rightarrow \max \\
\text { Sum } 2=\sum_{i=1}^{3} y_{i} \cdot b_{i} \rightarrow \max \\
\text { Entropy }=-\sum_{i=1}^{3} y_{i} \ln \left(y_{i}\right) \rightarrow \max \\
\sum_{i=1}^{3} y_{i}=1 ; \quad y_{i} \in[0 ; 1] .
\end{array}\right.
$$

The solution to problem (1) is a vector $\bar{Y}^{*}=\left(y_{1}, y_{2}, y_{3}\right)$ the optimal combination of the distribution of groups of loyal, random and Internet clients.

For the task, possible modifications are generated by various combinations of the Risk1, Risk2 and Sum1, Sum2 criteria in order to study the effectiveness or develop new loyalty programs.

Entropy Maximization Criteria provides a strategy to diversify a customer portfolio.

The second direction of modification of model (1) is to deepen the study of the customer portfolio to the level of each individual outlet. Then the sum of the optimal customer portfolios of a particular outlet forms the optimal portfolio of customers of the pharmacy chain as a whole. Let's introduce the following notation:

- $y_{k 1}$ - the share of loyal customers in the portfolio of clients of the $k$-th outlet;

$-y_{k 2}$ - the proportion of random customers of the $k$-th outlet;
- $y_{k 3}-$ the share of Internet customers of the $k$-th outlet;

- $b_{k i}$ - the average check for the $i$-th customer group (c. u.) of the $k$-th outlet;

- $\bar{b}_{k i}$ - the expected average check for the $i$-th customer group (c. u.) of the $k$-th outlet;

- $q_{k i}$ - the average frequency of visits in the $i$-th group of customers of the $k$-th outlet;

- $\bar{q}_{k i}$ - the expected average frequency of visits in the $i$-th customer group of the $k$-th outlet;

- $n$ - the number of pharmacies in the network.

$$
\left\{\begin{array}{l}
\text { Risk } 1=\sum_{k=1}^{n} \sum_{i=1}^{3} \sum_{j=1}^{3} y_{k i} \cdot y_{k j} \cdot\left(q_{k i}-\bar{q}_{k i}\right) \cdot\left(q_{k j}-\bar{q}_{k j}\right) \rightarrow \min , \\
\text { Risk } 2=\sum_{k=1}^{n} \sum_{i=1}^{3} \sum_{j=1}^{3} y_{k i} \cdot y_{k j} \cdot\left(b_{k i}-\bar{b}_{k i}\right) \cdot\left(b_{k j}-\bar{b}_{k j}\right) \rightarrow \min , \\
\text { Sum } 1=\sum_{k=1}^{n} \sum_{i=1}^{3} y_{k i} \cdot q_{k i} \rightarrow \max , \\
\text { Sum } 2=\sum_{k=1}^{n} \sum_{i=1}^{3} y_{k i} \cdot b_{k i} \rightarrow \max , \\
\text { Entropy }=-\sum_{k=1}^{n} \sum_{i=1}^{3} y_{k i} \ln \left(y_{k i}\right) \rightarrow \max , \\
\sum_{k=1}^{n} \sum_{i=1}^{3} y_{k i}=1 ; \quad y_{k i} \in[0 ; 1] .
\end{array}\right.
$$

The third type of model modifications (1) suggests instead of entropy to choose three other criteria that correspond to the priorities of a certain type of customers. It will be discussed in detail below.

Experiments with models (model verification) were carried out on the data of one of the pharmacy network operating in the city of Zaporizhzhia (Ukraine). Since there was no monitoring of the frequency of visits to customer groups by pharmacies, the study was carried out using a simplified model of the form:

$$
\left\{\begin{array}{l}
\text { Risk }=\sum_{i=1}^{3} \sum_{j=1}^{3} y_{i} y_{j}\left(b_{i}-\bar{b}_{i}\right)\left(b_{i}-\bar{b}_{i}\right) \rightarrow \min , \\
\text { Sum }=\sum_{i=1}^{3} y_{i} b_{i} \rightarrow \max , \\
\text { Entropy }=-\sum_{i=1}^{3} y_{i} \ln \left(y_{i}\right) \rightarrow \max .
\end{array}\right.
$$

Let's consider the solution of the multicriteria optimization problem (3) by the method of successive concessions. As is known, the method of successive concessions for solving multicriteria problems is applied in the case when partial criteria can be ordered in descending order of importance [13].

For definiteness, let's choose such an order relation: entropy, risk, income, that is, Entropy-Risk-Sum.

At the first stage, let's determine the optimal value of the first important criterion for Entropy in the field of feasible solutions.

$$
\begin{aligned}
& \text { Entropy }=-\sum_{i=1}^{3} y_{i} \ln \left(y_{i}\right) \rightarrow \max , \\
& \left\{\sum_{i=1}^{3} y_{i}=1 ; \quad y_{i} \in[0 ; 1] .\right.
\end{aligned}
$$

An optimal solution was obtained according to the second criterion Entropy*. 
Let's carry out the procedure for the next important Risk criterion, adding to the conditions that determine the acceptable solutions, the conditions for reducing the first Entropy criterion from the found optimal Entropy* value by no more than the values of the permissible concessions $\delta_{1}$ :

$$
\begin{aligned}
& \text { Risk }=\sum_{i=1}^{3} \sum_{j=1}^{3} y_{i} y_{j}\left(b_{i}-\bar{b}_{i}\right)\left(b_{i}-\bar{b}_{i}\right) \rightarrow \min , \\
& \left\{\begin{array}{l}
\text { Entropy } y^{*}-\text { Entropy } \leq \delta_{1} \text { Entropy }^{*} \\
\sum_{i=1}^{3} y_{i}=1 ; \quad y_{i} \in[0 ; 1]
\end{array}\right.
\end{aligned}
$$

Similarly, let's repeat for the criterion Sum, which is next in importance, adding to the conditions that determine the acceptable solutions, the conditions for reducing the first Entropy criterion and increasing by no more than the allowable concessions from the found optimal Risk* value $\delta_{1}$ :

$$
\begin{aligned}
& \text { Sum }=\sum_{i=1}^{3} y_{i} b_{i} \rightarrow \max , \\
& \left\{\begin{array}{l}
\text { Entropy }{ }^{*}-\text { Entropy } \leq \delta_{1} \text { Entropy }^{*}, \\
{\text { Risk}- \text { Risk }^{*} \leq \delta_{2} \text { Risk }^{*},}^{3} y_{i=1}=1 ; \quad y_{i} \in[0 ; 1] .
\end{array}\right.
\end{aligned}
$$
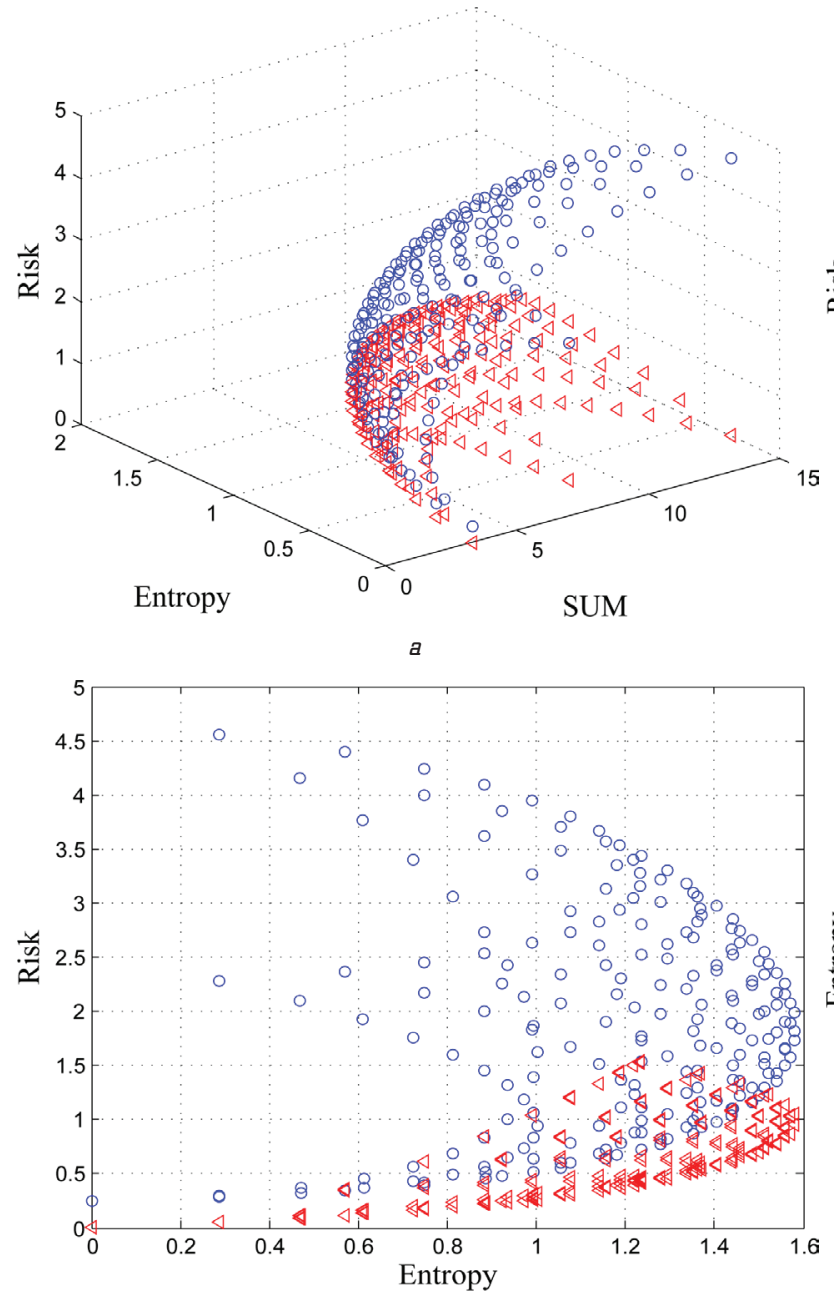

Fig. 1. Model solutions (3) built in the Matlab package: $a-3-d \_R \_5 \_E ; ~ b-R-5 ; c-R-E ; d-E-5$
The solution obtained in the third stage is the solution of the multicriteria problem of conditional optimization (1).

Fig. 1, $a$ shows the solutions according to the multicriteria model in the Entropy-Risk-Sum three-criteria space, which is built in the Matlab package [14]. The points indicated by blue circles correspond to the general risk; the red triangles indicate systemic risk.

Fig. $1, b-d$ shows the projection of the three-criteria space into the two-criteria space, for which one can observe the corresponding Pareto borders.

Let's study the model of the optimal customer portfolio for the entire centralized network of pharmacies with a different set of criteria depending on the marketing policy of the network; this is the third modification of the model (1). The results of the numerical experiment are presented in Table 1.

Table 1

Optimal portfolios and corresponding criteria values for a centralized pharmacy chain according to loyalty criteria for various customer groups

\begin{tabular}{|c|c|c|c|}
\hline Indicators & Network 1 Loyal & Network 2Loyal & Network 3Loyal \\
\hline SUM*1 $^{*} 0^{3}$ & 15.305731 & 8.887202 & 3.377131 \\
\hline HISK & 4.9 & 2.434317 & 0.255287 \\
\hline GroupLoyal & 99009.7 & 99009.439908 & 110000 \\
\hline Y=y1 & 0.9891 & 0.0010 & 0.0010 \\
y2 & 0.0099 & 0.9891 & 0.0090 \\
y3 & 0.0010 & 0.0099 & 0.9900 \\
\hline
\end{tabular}
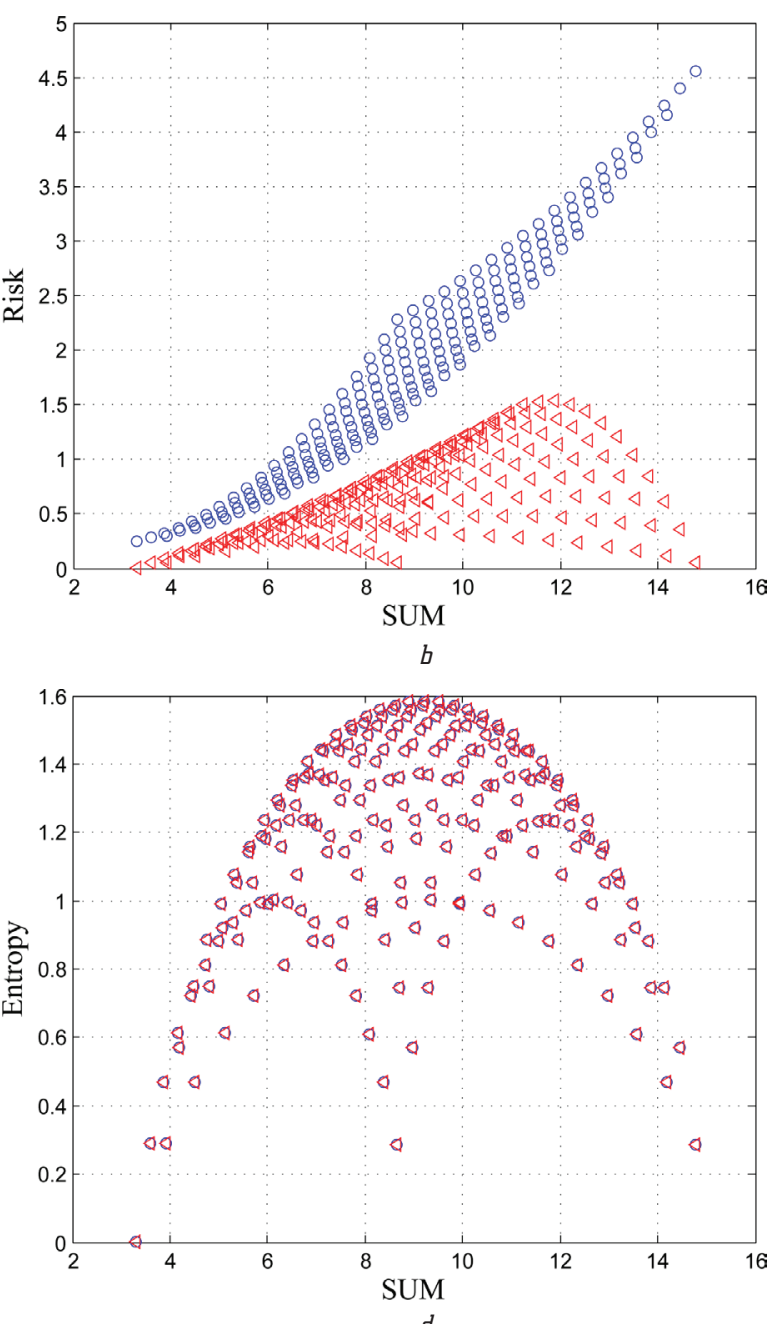

d 
The case is considered when instead of a diversified portfolio of clients, preference is given to loyal customers. Let's replace entropy maximization with a criterion of the form:

$$
\begin{aligned}
& \text { 1Loyal }=y_{1} / y_{2} / y_{3} \rightarrow \max , \\
& \left\{\begin{array}{l}
\text { Risk } 2=\sum_{i=1}^{3} \sum_{j=1}^{3} y_{i} y_{j}\left(b_{i}-\bar{b}_{i}\right)\left(b_{i}-\bar{b}_{i}\right) \rightarrow \min , \\
\text { Sum } 2=\sum_{i=1}^{3} y_{i} b_{i} \rightarrow \max , \\
1 \text { Loyal }=y_{1} / y_{2} / y_{3} \rightarrow \max , \\
\sum_{i=1}^{3} y_{i}=1 ; \quad y_{i} \in[0 ; 1] .
\end{array}\right.
\end{aligned}
$$

For a portfolio in which preference is given to random visitors, the criterion is used:

$$
\text { 2Loyal }=y_{2} / y_{1} / y_{3} \rightarrow \max
$$

For a marketing policy aimed at maximizing the number of Internet clients, let's use the criterion:

$$
\text { 3Loyal }=y_{3} / y_{1} / y_{2} \rightarrow \max \text {. }
$$

Similar studies are conducted for individual pharmacies belonging to the same network, but have different composition of the initial customer portfolio. Table 2 presents the optimal portfolios for individual pharmacies according to the loyalty criteria for various customer groups.

Tahle 2

Optimal portfolios and corresponding criteria values for individual pharmacies according to loyalty criteria for various customer groups

\begin{tabular}{|c|c|c|c|c|}
\hline Indicators & $\begin{array}{c}\text { Network } \\
\text { ENTR_COV_SUM }\end{array}$ & $\begin{array}{c}\text { Pharmacy } 1 \\
\text { ENTR_CDV_SUM }\end{array}$ & $\begin{array}{c}\text { Pharmacy } 2 \\
\text { ENTR_CDV_SUM }\end{array}$ & $\begin{array}{c}\text { Pharmacy } 3 \\
\text { ENTR_COV_SUM }\end{array}$ \\
\hline SUM $^{*} \cdot 10^{3}$ & 7.5205 & 10.954903 & 23.7035 & 3.749267 \\
\hline RISK & 1.1 & 2.5 & 11.7 & 0.8 \\
\hline Entr & 1.4265 & 1.426466 & 1.4265 & 1.527519 \\
\hline $\begin{array}{c}Y=y 1 \\
\text { y2 } \\
\text { y3 }\end{array}$ & $\begin{array}{l}0.2637 \\
0.1821 \\
0.5542\end{array}$ & $\begin{array}{l}0.1620 \\
0.5394 \\
0.2987\end{array}$ & $\begin{array}{l}0.4533 \\
0.1301 \\
0.4166\end{array}$ & $\begin{array}{l}0.3971 \\
0.3971 \\
0.2057\end{array}$ \\
\hline
\end{tabular}

\begin{tabular}{|c|c|c|c|}
\hline Indicators & $\begin{array}{c}\text { Pharmacy 1 } \\
\text { 1 Loyal }\end{array}$ & $\begin{array}{c}\text { Pharmacy 2 } \\
\text { 2Loyal }\end{array}$ & $\begin{array}{c}\text { Pharmacy 3 } \\
\text { 3Loyal }\end{array}$ \\
\hline SUM $^{*} \cdot 10^{3}$ & 40.737413 & 69.588454 & 11.590556 \\
\hline HISK & 35.3 & 258.9 & 8.6 \\
\hline GroupLoyal & 99009.7 & 99015.5 & 100415.2 \\
\hline Y=y1 & 0.9891 & 0.0010 & 0.0010 \\
y2 & 0.0099 & 0.9890 & 0.0099 \\
y3 & 0.0010 & 0.0100 & 0.9891 \\
\hline
\end{tabular}

For ease of comparison, the results of experiments according to model (3) for a centralized pharmacy network and its individual pharmacies are summarized in Table 3.

Optimal portfolios and corresponding criteria values according to model (3) for centralized pharmacy network and individual pharmacies
Comparing the data in Table 1 and the first column of Table 3, it can be seen that the transition of the network to a diversification strategy is attractive when, at the initial moment, Internet clients dominate the network portfolio or change the composition of the portfolio in favor of the loyal ones, that is, develop loyalty programs. When comparing Table 1 and Table 2 of the network as whole and individual pharmacies with appropriate marketing strategies, it is possible to conclude that separating the pharmacy from the network leads to a small increase in revenue with a significant increase in risk, especially for pharmacies that have a significant proportion of casual visitors in the portfolio. A comparison of the corresponding pharmacies (with the same initial conditions) according to Table 2 and Table 3 indicates that with the transition of the pharmacy to the diversification strategy, there is a slight decrease in income with a significant reduction in risk, again especially for pharmacies that have a significant proportion of casual visitors in the portfolio. A comparison according to the data of Table 3 of individual pharmacies with the network as a whole (first column) under the conditions of a diversification strategy suggests that separation from the network in the case of Pharmacy 3 will lead to a slight decrease in income and risk, but for others it will increase.

According to the experiments, it is worth noting that pharmacy network in the practice of risk management make sense to consider all variants of model modifications (1).

\section{SWOT analysis of research results}

Strengths. The strengths of the research and application of modeling the risk management process of a centralized pharmacy network is that these measures allow to get the optimal combination of the distribution of groups of loyal, random and online clients. This will help increase the average bill and frequency of purchase for each group of customers. Thus, the proposed model allows to develop effective methods to minimize losses and maximize revenue.

Weaknesses. The analysis of the implementation of models is carried out on the data of one of the pharmacy network. Since the frequency of visits is not monitored, the studies had to be performed using a simplified model.

Opportunities. It should be noted that the model of the optimal client portfolio of a centralized pharmacy network should be considered as part of a comprehensive program of diversification of the pharmacy network, taking into account the activities of suppliers, chains and customers. In the future, it is planned to investigate the features of

diversification models of the holding and the

Table 3 mixed type of pharmacy network. It is also possible to use recommender systems to form an optimal portfolio using recommendations.

Threats. The threats to managing the optimal client portfolio of a centralized pharmacy chain include modern conditions for the functioning of pharmacy network in a competitive market environment and legislative changes.

\section{Conclusions}

1. In this paper, models are constructed for making decisions on choosing the optimal combination of the distribution of groups of loyal, 
random and Internet clients for the further development of programs for influencing these groups. The described multi-criteria models based on a portfolio approach with various sets of criteria are aimed at minimizing the risks of losing customers of a certain group and maximizing profits.

2. The constructed models are verified on the real data of one of the pharmacy network in Zaporizhzhia (Ukraine). The result of modeling the optimal client portfolios of a centralized pharmacy chain is the ability to eliminate shortcomings in network management and the choice of the optimal combination of the distribution of groups of loyal, random and online clients.

The practical value of the modeling carried out in this work is confirmed by a series of experiments conducted on real data, which demonstrate the possibility of using the developed tool for the automatic distribution of customer groups of centralized pharmacy network in the form of parenteral optimal portfolios in order to minimize risks. Among the areas of further research is conducting a series of experiments with various methods of formalizing risk in portfolio models and searching for relevant analytical dependencies.

3. Recommendations are formed based on the results of experiments that may be useful for automating the business processes of pharmacy network, risk management, analysis of loyalty programs to increase the efficiency of their functioning.

\section{Acknowledgement}

The work was carried out as the part of the research work «Mathematical modeling of socio-economic processes and systems», the registration number DB05038, at the Department of System Analysis and Computational Mathematics of Zaporizhzhia National Technical University.

\section{References}

1. Frederick, F., Thomasm, A. (1996). Teal Reichheld The Loyalty Effect: The Hidden Force Behind Growth, Profits, and Lasting Value. Harvard Business School Press, 323.

2. Kotler, F. (2012). Marketing menedzhment. Saint Petersburg: Piter, 752.

3. Dzyuba, P. V. (2017). Conceptual structure of portfolio theory as a paradigmatic fundamental of international portfolio investing contemporary theory. Scientific Bulletin of Uzhgorod National University, 15 (1), 100-106.
4. Markowitz, H. M. (1959). Portfolio Selection: Efficient Diversification of Investments. London: Chapman \& Hall, Ltd.; Cowles Foundation for Research in Economics at Yale University, 344.

5. Guerard, J. B. (2010). Markowitz and the Expanding Definition of Risk: Applications of Multi-factor Risk Models. Handbook of Portfolio Construction. Contemporary Applications of Markowitz Techniques. New York, Dordrecht, Heidelberg, London: Springer, 31-60. doi: http://doi.org/10.1007/978-0-387-77439-8_2

6. Van der Weide, H. (2010). Principles for Lifetime Portfolio Selection: Lessons from Portfolio Theory James. Handbook of Portfolio Construction. Contemporary Applications of Markowitz Techniques. New York, Dordrecht, Heidelberg, London: Springer, 153-178. doi: http://doi.org/10.1007/978-0-387-77439-8 7

7. Campbell, J. Y., Viceira, L. M. (2006). Strategic Asset Allocation: Portfolio Choice for Long-term Investors. New York: Oxford University Press, 274.

8. Dell'Aquila, R., Embrechts, P. (2006). Extremes and Robustness: A Contradiction? Financial Markets and Portfolio Management, 20 (1), 103-118. doi: http://doi.org/10.1007/s11408-006-0002-x

9. Clark, A., Labovitz, M. (2006). Securities selection and portfolio optimization: Is money being left on the table? Financial Engineering and Applications. Canada: Acta Press, 131.

10. Petrichm, D. M., Kahnm, R. N. (2010). What Matters Most in Portfolio Construction? Handbook of Portfolio Construction. Contemporary Applications of Markowitz Techniques. New York, Dordrecht, Heidelberg, London: Springer, 481-492. doi: http:// doi.org/10.1007/978-0-387-77439-8 16

11. Kyshakevych, B. Yu. (2010). Formuvannia optymalnykh za Pareto kredytnykh portfeliv z dopomohoiu henetychnoho alhorytmu. Visnyk Khmelnytskoho natsionalnoho universytetu, 4, 126-132.

12. Posylkina, O. V. Aptechna merezha. Available at: https://www. pharmencyclopedia.com.ua/article/2856/aptechna-merezha

13. Shtoier, R. (1992). Mnogokriterialnaia optimizaciia. Moscow: Radio i sviaz, 504.

14. Academic version of MATLAB. Available at: https://www.mathworks.com/academia.html

Bakurova Anna, Doctor of Economic Sciences, Professor, Department of Systems Analysis and Computational Mathematics, Zaporizhzhia Polytechnic National University, Ukraine, ORCID: http:// orcid.org/0000-0001-6986-3769, e-mail: abaka111060@gmail.com

Ropalo Hanna, Postgraduate Student, Department of Systems Analysis and Computational Mathematics, Zaporizhzhia Polytechnic National University, Ukraine, ORCID: http://orcid.org/0000-00015241-6911, e-mail: annropalo@gmail.com

Tereschenko Elina, PhD, Associate Professor, Department of Systems Analysis and Computational Mathematics, Zaporizhzhia Polytechnic National University, Ukraine, ORCID: http://orcid.org/ 0000-0001-6207-8071, e-mail: elina_vt@ukr.net 